\title{
Nervous System Findings Domain
}

National Cancer Institute

\section{Source}

National Cancer Institute. Nervous System Findings Domain. NCI Thesaurus. Code C102677.

A subject domain utilized for the submission of information encompassing and representing data, vocabulary or records related to nervous system findings. 